\author{
産業医科大学 整形外科たなか整形外科医院* \\ 大茂壽久（おおしげとしひさ）酒井昭典 古江幸博 中河原 修 \\ 田中邦彦* 中村利孝
}

【はじめに】遠位撓尺関節背側脱臼を伴った前腕骨の急性塑性変形に対して、徒手整復にて加 療した一例を経験したので文献的考察を加えて報告する。【症例】10歳 男児。約 $1 \mathrm{~m}$ のフンン スを飛び越えようとしたところ、服が引つ掛かり右手から転落し、受傷。翌日、当科初診し、 右前腕から手関節にかけてのびまん性の腫脹と疼痛があり、また前腕の著明な回外制限（-10 度）を認めた。単純X線で、橈骨、尺骨ともに、掌側凸の驾曲をきたし、尺骨頭は背側に脱臼し ていた。骨折線は認めなかった。以上の所見より遠位撓尺関節背側脱臼を伴った右前腕骨急性 塑性変形と診断した。受傷から3日後に、全身麻酔下に徒手整復を行い、前腕の回旋制限が消失 したことを確認の上、回外位にて7週間のギプス固定を行った。受傷後一年の現在、可動域制限 もなく、経過良好である。

\title{
2-3-6 前腕骨骨幹部骨折に対する蹃内釘 (TRUE/FLEX)の使用経験
}

宮崎県立延岡病院 整形外科

○田口 学（たぐちまなぶ）、谷脇功一、木屋博昭、

弓削孝雄、金井一男、仙波 圭、川谷洋右、池尻洋史

【目的】前腕骨骨幹部骨折は保存的には転位の整復、保持が困難なことが多くプレート固定 等の観血的治療が一般的である。今回われわれは閉鎖性髄内釘システム (TRUE/FLEX) を 用い比較的良好な結果が得られたので報告する。

【対象・方法】1998年7月より1999年1月に当科にて（TRUE/FLEX）を用いて加療した前 腕骨骨幹部骨折4例（男3例、女1例）を対象とした。年齢は19〜78歳（平均48歳）であっ た。両骨骨折が 3 例であり残りの 1 例は尺骨単独骨折であった。術後は2例は1週間の外固定 とし他の 2 例は三角巾固定のみとした。

【結果】術直後の症例以外ではいずれも骨癒合は良好であり、著しい可動域制限等も認めて いない。手術侵襲及び釷刺入部の疼痛も小さく選択されて良い治療法の 1 つであると考えら れた。 


\section{第 2 日第 3 会場 午前}

\section{2-3-7 Orthofix 創外固定器を用いた上腕骨遠位端骨折の治療経験}

\section{公立玉名中央病院整形外科}

○清家一郎（せいけいちろう）、中野哲雄、阿部靖之 清水泰宏、越智龍弥、岩本克也

【目的】不安定な上腕骨遠位端骨折に対して、Orthofix創外固定器での加療 4 症例について、その意義 を検討する。

【方法】対象は男性 1 例、女性 3 例。59９2才（平均80.5 才）。手術法は全例骨折型に応じtension band wiring法やcanulated cancellous screwで内固定した上で、オルソフィックス創外固定器を使用し た。術後 2〜3 日で肘の可動域訓練を行い、高齢者でも術後 $6 〜 8$ 週間で創外固定の抜釘を行った。 【結果】、全例Wheelerの判定基準でGood以上の成績であり、骨癒合も良好であった。骨粗鬆症の著 明な症例や粉砕骨折に対しては、内固定に加えて、前腕の回内・回外を制限されず、肘関節の伸展 · 屈曲の軸と固定器のヒンジがー致したOrthofix創外固定器の併用は早期に関節可動域訓練が開始でき、 有用な方法であると考えられる。

\section{2-3-8 上腕骨骨幹部骨折に対する髄内釘固定}

\section{鹿児島市立病院 整形外科}

○山下 芳隆（やました よしたか）、谷口 良康、牧信哉、 濱里雄次郎、折口 信夫、中村 真

【目的】当院の上腕骨骨幹部骨折に対する髄内釘固定法の成績及び問題点を報告する。【症例及び 方法】平成 2 年 9 月から平成 10 年 5 月まで当院で髄内釘にて手術した 20 症例 20 肢を対象とした。 男 8例、女 12 例、右 10 肢、左 10 肢、手術時年齢は 19〜80 歳 (平均 47歳)、骨折型はAO/ASIF 分類で A2 : 3 例、A3:11例、B2:4例、C2 : 2例であった。髄内釘の種類はEnder 釘 15 例、Rush pin5例であった。調査項目として、(1)骨癒合及び変形治療の有無(2)肩及び时の術後可動域(3)髄内 釘による合併症を検討した。【結果】20 例中 18 例で骨癒合が得られたが 2 例で 15 度以上の屈曲 変形を残し変形癒合亡判断した。変形治療例は骨䯣内径が狭く、Rush pin $1 〜 2$ 本使用した症 例であった。術後可動域は 20 例中肩 2 例、肘 1 例で制限があった。【考祭】䯣内釗固定法は優れ た骨接合法と考えるが、小柄で骨髄内径の狭い症例にはプレート法などを用いるべきと考えた。 